EDUCATIONAL : Jurnal Inovasi Pendidikan dan Pengajaran

Vol. 1 No. 4 November 2021 e-ISSN : 2775-2593 | p-ISSN : 2775-2585

\title{
PENERAPAN PEMBELAJARAN KOOPERATIF MODEL GROUP TO GROUP EXCHANGE UNTUK MENINGKATKAN HASIL BELAJAR SISWA PADA POKOK BAHASAN SENYAWA HIDROKARBON
}

\author{
ANIK ANDRIYANI \\ SMA Negeri 2 Jember \\ e-mail: anikandriyani660@gmail.com
}

\begin{abstract}
ABSTRAK
Penelitian tindakan kelas ini secara umum bertujuan untuk meningkatkan kualitas pembelajaran siswa kelas XI SMAN 2 Jember tahun pelajaran 2018-2019, dan secara khusus untuk mengetahui hasil belajar siswa dengan menggunakan pembelajaran kooperatif model Group to Group Exchange pada pokok bahasan Senyawa Hidrokarbon. Penelitian dilaksanakan dalam dua siklus, dimana masing-masing siklus terdiri dari tahap perencanaan, pelaksanaan, pengamatan, dan refleksi. Data nilai afektif siswa digali dengan lembar observasi, sementara data nilai hasil belajar siswa diambil dari tes hasil belajar. Hasil penelitian menunjukkan bahwa (1) hasil nilai afektif dari siswa kelas XI MIPA 4 pada pokok bahasan Senyawa Hidrokarbon pada siklus 2 mengalami peningkatan, (2) nilai hasil belajar siswa kelas XI MIPA 4 pada pokok bahasan Senyawa Hidrokarbon mengalami peningkatan dibanding tahun pelajaran sebelumnya setelah menggunakan pembelajaran kooperatif model Group to Group Exchange.
\end{abstract}

Kata Kunci: Pembelajaran kooperatif, Group to Group Exchange, Senyawa Hidrokarbon

\begin{abstract}
This classroom action research generally aimed to improve the quality of learning for $11^{\text {th }}$ grade students of SMAN 2 Jember in the 2018-2019 school year, and especially aimed to improve student learning results through cooperative learning with Group to Group Exchange model on the Hydrocarbon Compounds subject. This research is conducted in two cycles, which each cycle composed of planning, implementation, observation, and reflection. The results of affective value of students were taken from observation sheet, while data of student's learning outcomes were taken from learning outcomes test. The results of this research showed that (1) The results of affective value of class XI MIPA 4 SMAN 2 Jember on the Hydrocarbon Compounds in cycle 2 experienced an increase, (2) The student learning outcomes of students in $11^{\text {th }}$ grade (XI MIPA 4) SMAN 2 Jember on the Hydrocarbon Compounds increased if compared to the previous year after Group to Group Exchange model was applied.
\end{abstract}

Keywords: Cooperative learning, Group to Group Exchange, Hydrocarbon Compound

\section{PENDAHULUAN}

Keberhasilan pembelajaran tidak terlepas dari peranan seorang pendidik dan peserta didik secara integral. Kesiapan pendidik dan peserta didik dalam proses pembelajaran merupakan salah satu aspek yang menunjang keberhasilan pembelajaran. "Mengajar bukan semata persoalan menceritakan, belajar bukanlah konsekwensi otomatis dari penuangan informasi ke dalam benak siswa, belajar memerlukan keterlibatan mental dan kerja siswa sendiri" (Silberman, 2016). Untuk mencapai keberhasilan pembelajaran, proses pembelajaran dilaksanakan dengan pedagogi yang mencakup strategi dan metode. Salah satu metode pembelajaran adalah "Belajar Kooperatif" (Cooperative Learning).

Pembelajaran kooperatif merupakan strategi pembelajaran yang mengutamakan adanya kerjasama antar siswa dalam kelompok untuk mencapai tujuan pembelajaran. Para siswa dibagi dalam kelompok-kelompok kecil dan diarahkan untuk mempelajari materi pelajaran yang telah ditentukan. Belajar kooperatif adalah kegiatan yang berlangsung dalam lingkungan belajar sehingga siswa dalam kelompok kecil saling berbagi ide-ide dan bekerja sama untuk menyelesaikan tugas akademik. Davidson \& Kroll (dalam Hobri, 2009:43). As'ari (dalam Hobri, 2009:43) menyatakan bahwa di dalam belajar kooperatif, siswa tidak hanya dituntut 


\section{Vol. 1 No. 4 November 2021 e-ISSN : 2775-2593 | p-ISSN : 2775-2585}

secara individual berupaya untuk mencapai sukses atau berusaha mengalahkan rekan mereka, melainkan dituntut untuk bertanggung jawab terhadap keberhasilan kelompoknya.

Menurut Mulyasa (2004:32) bahwasanya pembelajaran dikatakan berhasil apabila sebagian peserta didik terlibat secara aktif, baik fisik, mental, maupun sosial dalam proses pembelajaran, di samping menunjukkan kegairahan belajar tinggi, semangat belajar tinggi, rasa percaya diri pada diri sendiri. Menurut Silberman (2016) dalam pembelajaran aktif peserta didik berupaya untuk mengajukan pertanyaan. Peserta didik yang mengajukan pertanyaan sendiri berarti peserta didik tersebut memiliki keingintahuan yang besar terhadap materi yang dipelajari. Pada akhirnya peserta didik berusaha menuntaskan pertanyaan mereka dengan mencari informasi dari buku, berdiskusi dengan peserta didik lain dan dapat juga berdiskusi dengan guru.

Melvin (2016) menyatakan, sebagian pakar percaya bahwa sebuah mata pelajaran baru benar-benar dikuasai ketika si pembelajar mampu mengajarkannya kepada orang lain. Pengajaran sesama siswa memberi siswa kesempatan untuk mempelajari sesuatu dengan baik dan sekaligus menjadi nara sumber bagi satu sama lain. Model Group to Group Exchange merupakan salah satu cara praktis untuk mengadakan pengajaran sesama siswa di kelas. Model ini juga memungkinkan guru untuk memberi tambahan, bila dirasa perlu, pada pengajaran oleh siswa.

Dharyani (2010:176) menuliskan bahwa model Pembelajaran Group to Group Exchange adalah memberikan tugas berbeda kepada para kelompok peserta yang kemudian setiap kelompok "mengajarkan" apa yang dipelajari kepada semua kelompok peserta. Menurut Hardiwati (2013:137) model pembelajaran Group to Group Exchange adalah memberikan tugas berbeda-beda diberikan kepada kelompok yang berbeda-beda. Setiap kelompok lalu "mengajarkan" hal-hal yang sudah dipelajarinya kepada murid-murid lainnya.

Pendapat-pendapat di atas pada dasarnya memiliki pandangan yang sama, yaitu mendefinisikan model pembelajaran Group to Group Exchange sebagai model pembelajaran yang menuntut peserta didik untuk selalu aktif dalam pembelajaran, saling mengajarkan kepada sesama peserta didik dengan cara berinteraksi antar kelompok, setiap kelompok diberikan kesempatan untuk saling bertukar materi yang diterimanya dan dituntut untuk menjelaskan kepada temannya dalam kelompok lain tentang tugas yang diterimanya, sehingga siswa termotivasi untuk menguasai materi pembelajaran yang disajikan.

Materi "Senyawa Hidrokarbon" adalah materi yang sangat penting dalam pembelajaran kimia. Pengetahuan dasar tentang senyawa hidrokarbon yang mencakup Alkana, Alkena, dan Alkuna merupakan landasan untuk dapat memahami konsep-konsep kimia yang lain, seperti Senyawa Turunan Alkana, Haloalkana, Reaksi senyawa karbon, Benzena, Polimer, Karbohidrat, Protein, maupun Lemak. Senyawa hidrokarbon juga merupakan bahan kimia yang besar penggunaannya dalam kehidupan sehari-hari.

Penelitian tindakan kelas ini mengacu pada hasil belajar siswa pada pokok bahasan "Senyawa Hidrokarbon" selama ini kurang memuaskan. Dengan penggunaan metode pembelajaran konvensional yaitu ceramah, siswa terlihat kurang tertarik dan kurang bersemangat dalam belajar. Hal ini menyebabkan hasil belajar peserta didik belum sesuai dengan harapan. Berdasarkan analisis hasil ulangan harian, sekitar $42 \%$ peserta didik belum tuntas atau belum mencapai KKM (Kriteria Ketuntasan Minimum). KKM untuk pelajaran kimia kelas XI di SMA Negeri 2 Jember bedasarkan hasil musyawarah guru mata pelajaran sekolah (MGMPS) adalah 80. Sementara ketuntasan klasikal tercapai apabila 85\% atau lebih siswa dalam kelas mendapatkan nilai $\geq 80$.

Dari paparan di atas, peneliti mencoba untuk mengoptimalkan hasil belajar siswa pada pokok bahasan "Senyawa Hidrokarbon" melalui penerapan pembelajaran kooperatif dengan model Group to Group Exchange. Dengan model tersebut, diharapkan materi senyawa hidrokarbon dapat dipahami dengan baik oleh siswa dan mampu meningkatkan hasil belajar siswa. 


\section{Vol. 1 No. 4 November 2021 e-ISSN : 2775-2593 | p-ISSN : 2775-2585}

Tujuan penelitian pada penelitian tindakan kelas ini adalah untuk mengetahui efektifitas pembelajaran kooperatif model Group to Group Exchange untuk meningkatkan hasil belajar siswa kelas XI MIPA 4 pada pokok bahasan Senyawa Hidrokarbon di SMA Negeri 2 Jember. Pemilihan model pembelajaran Group to Group Exchange ini diharapkan dapat menjadikan belajar kimia lebih menyenangkan untuk siswa, serta meningkatkan keterlibatan siswa dalam proses pembelajaran, serta dapat menarik minat guru lain di lingkungan MGMPS untuk menggunakan model pembelajaran ini dalam melaksanakan tugas mengajarnya.

\section{METODE PENELITIAN}

Penelitian ini termasuk jenis Penelitian Tindakan Kelas yang ingin mengoptimalkan kemampuan siswa dalam memahami pokok bahasan Senyawa Hidrokarbon. Penelitian tindakan kelas dilaksanakan dengan penjadwalan waktu sebagai berikut: (1) Tahap perencanaan dilaksanakan minggu ke 3 - 4 bulan Juli 2018. (2) Tahap pelaksanaan dan pengumpulan data dilaksanakan minggu ke 1 - 2 bulan Agustus 2018. (3) Tahap pengolahan data dan penulisan laporan dilaksanakan minggu ke 3 bulan Agustus sampai dengan minggu ke 1 bulan September 2018. Penelitian tindakan kelas dilakukan di SMA Negeri 2 Jember, J1 Jawa no. 16 Jember. Subyek dalam penelitian tindakan kelas ini adalah siswa kelas XI MIPA 4 SMA Negeri 2 Jember yang berjumlah 38 siswa pada semester gasal tahun pelajaran 2018-2019.

Prosedur Penelitian Tindakan Kelas ini direncanakan dalam 2 siklus. Masing-masing siklus terdiri dari (1) Perencanaan tindakan (2) Pelaksanaan tindakan (3) Pengamatan/pengumpulan data, dan (4) Refleksi. Jika pada pelaksanaan siklus I telah tercapai ketuntasan secara klasikal, maka pelaksanaan siklus dihentikan. Tetapi jika hasil yang dicapai belum mencapai ketuntasan secara klasikal, maka dilanjutkan pada pelaksanaan tindakan siklus II.

Siklus pada kegiatan penelitian tindakan kelas tersebut digambarkan seperti diagram di bawah.

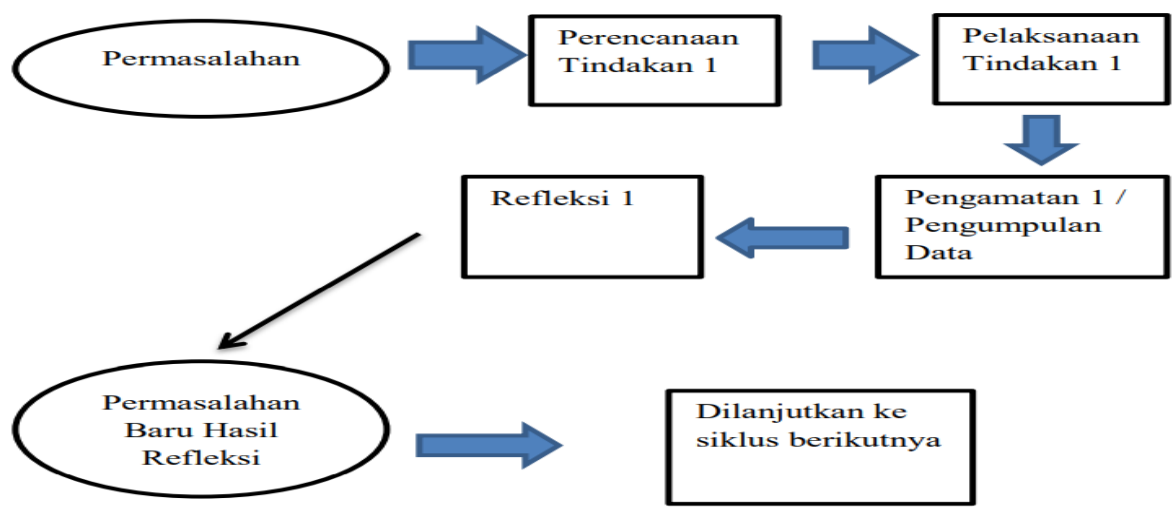

Gambar 1. Siklus kegiatan PTK

(Suharsimi Arikunto dkk : 2006)

Kegiatan pertama pada masing-masing siklus adalah persiapan tindakan. Dalam persiapan tindakan ini peneliti melakukan (1) menyusun silabus dan sistem penilaian pada pokok bahasan Senyawa Hidrokarbon. (2) menyusun RPP tentang Senyawa Hidrokarbon yang digunakan dalam penelitian tindakan kelas. (3) menyusun lembar kegiatan siswa yang berupa penugasan. (4) membuat 6 kelompok siswa. (5) membuat lembar observasi dan penskoran (6) membuat soal tes hasil belajar dan penskoran (7) menyiapkan lembar analisis hasil tes (8) menyusun langkah-langkah pada pelaksanaan tindakan dengan menggunakan pembelajaran kooperatif model Group to Group Exchange.

Teknik pengumpulan data digunakan teknik observasi dan tes hasil belajar. Teknik observasi digunakan untuk mengumpulkan data selama proses pembelajaran berlangsung dengan menggunakan instrumen lembar observasi. Untuk mengumpulkan nilai hasil belajar 
siswa digunakan tes hasil belajar. Tes ini berupa lembar evaluasi yang berisikan soal-soal pilihan ganda yang diberikan guru diakhir proses pembelajaran.

\section{HASIL DAN PEMBAHASAN}

\section{Hasil}

Pelaksanaan tindakan pada tiap siklus sudah dilakukan sesuai dengan langkah-langkah seperti dalam perencanaan. Pada siklus II dilakukan penggantian pada lembar kegiatan siswa. Hasil dari tahap-tahap yang telah dilaksanakan pada tiap siklus dipaparkan di bawah ini.

Hasil observasi terhadap penilaian afektif pada pelaksanaan tindakan siklus I mempunyai tingkat ketercapaiannya sebagai berikut:

Tabel 1. Tingkat ketercapaian nilai afektif pada pelaksanaan siklus I

\begin{tabular}{ll}
\hline Aspek Penilaian & Tingkat Ketercapaian \\
\hline Sikap & $74 \%$ siswa mendapatkan nilai $\geq \mathrm{B}$ \\
\hline
\end{tabular}

Nilai hasil belajar pada pelaksanaan tindakan siklus I diperoleh dari jawaban siswa dengan memberikan skor satu untuk jawaban benar, dan skor nol untuk jawaban salah pada setiap butir soal berpedoman pada kunci jawaban dan dengan rumus yang sudah ditetapkan. Tingkat ketercapaian hasil belajar pada pelaksanaan tindakan siklus I sebagai berikut:

Tabel 2. Tingkat ketercapaian hasil belajar pada pelaksanaan siklus I

\begin{tabular}{lcl}
\hline Nilai & Jumlah Siswa & Prosentase \\
\hline $80-95$ & 22 & $58 \%$ \\
\hline
\end{tabular}

Ketercapaian hasil belajar pada pelaksanaan tindakan siklus I, baik dari aspek sikap dan hasil belajar, disajikan dalam bentuk grafik di bawah ini.

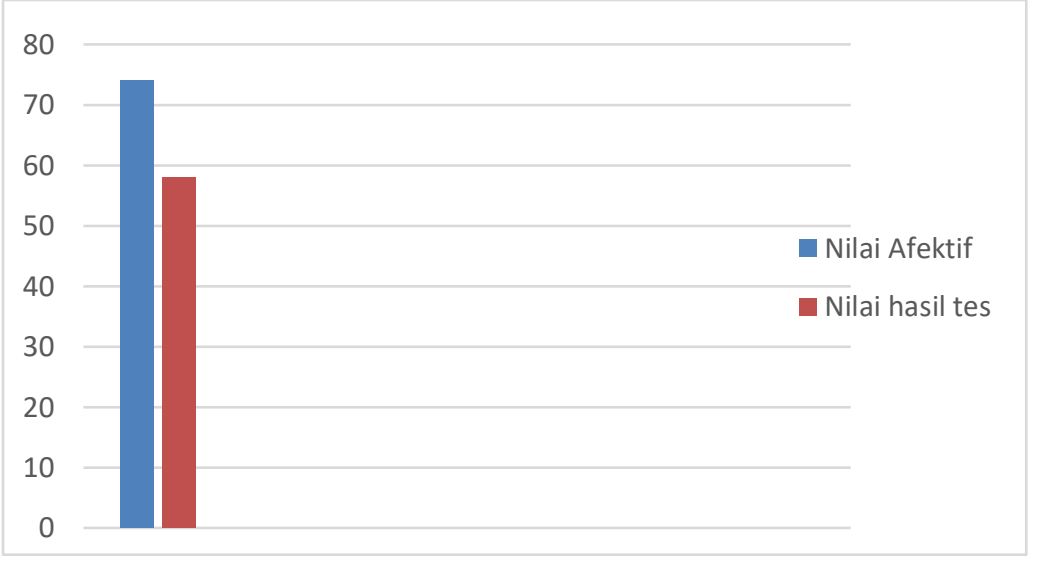

Gambar 2. Grafik peningkatan hasil belajar siswa

Pada pelaksanaan tindakan siklus II, sesuai dengan perencanaan, dengan mengganti lembar kerja siswa, didapatkan hasil seperti dipaparkan di bawah. Hasil observasi terhadap aspek afektif mempunyai tingkat ketercapaian sebagai berikut:

Tabel 3. Tingkat ketercapaian nilai afektif pada pelaksanaan siklus II

\begin{tabular}{ll}
\hline Aspek Penilaian & Tingkat Ketercapaian \\
\hline Sikap & $95 \%$ siswa mendapatkan nilai $\geq \mathrm{B}$ \\
\hline
\end{tabular}

Tingkat ketercapaian hasil belajar pada pelaksanaan tindakan siklus II sebagai berikut: 
Vol. 1 No. 4 November 2021 e-ISSN : 2775-2593 | p-ISSN : 2775-2585

\section{Tabel 4. Tingkat ketercapaian hasil belajar pada pelaksanaan siklus II}

\begin{tabular}{lcl}
\hline Nilai & Jumlah Siswa & Prosentase \\
\hline $80-95$ & 33 & $87 \%$ \\
\hline
\end{tabular}

Ketercapaian hasil belajar pada pelaksanaan tindakan siklus II, baik dari aspek sikap dan hasil belajar, disajikan dalam bentuk grafik di bawah ini.

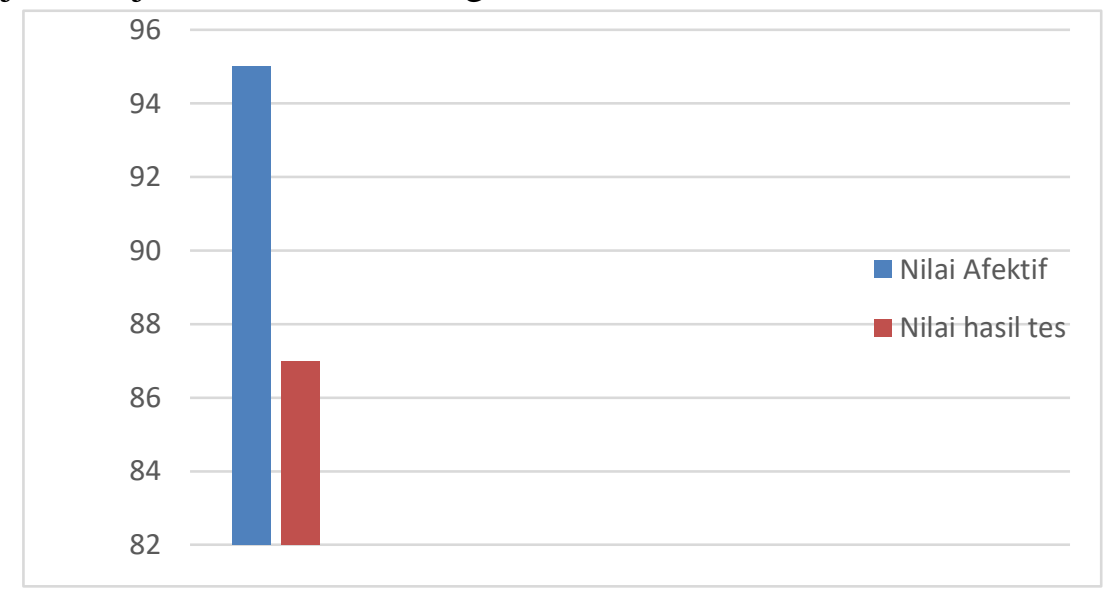

Gambar 3. Grafik peningkatan hasil belajar siswa

\section{Pembahasan}

Penggunaan pembelajaran kooperatif model Group to Group Exchange pada pokok bahasan Senyawa Hidrokarbon dapat berjalan walaupun masih terdapat kendala. Belum tercapainya ketuntasan secara klasikal pada kegiatan pembelajaran di siklus I, menjadikan peneliti melanjutkan dengan melaksanakan kegiatan pembelajaran pada siklus II.

Hasil analisis data dari hasil observasi terhadap penilaian sikap pada pelaksanaan tindakan siklus I, terdapat 22 siswa yang mendapatkan nilai B ( tingkat ketercapaian 58\%). Sementara itu dari tes hasil belajar pada pelaksanaan tindakan siklus I menunjukkan hasil dimana 22 siswa (58\% siswa) yang mendapatkan nilai $\geq 80$.

Hasil evaluasi peneliti terhadap ketidakberhasilan pelaksanaan pembelajaran pada siklus I antara lain adalah kurang ketatnya guru (dalam hal ini adalah peneliti) dalam mengatur penggunaan waktu untuk setiap kegiatan pembelajaran, serta belum terbiasanya siswa dalam bekerja secara kooperatif. Berdasarkan data perolehan skor pada tiap-tiap indikator pada penilaian aspek afektif, ditemukan bahwa keaktifan siswa dalam kerja kelompok pada pelaksanaan tindakan siklus I masih rendah. Hal ini sesuai dengan yang disampaikan Dess bahwa dalam pembelajaran kooperatif ada beberapa kelemahan, antara lain adalah:1) membutuhkan waktu yang lama bagi siswa, sehingga sulit mencapai target kurikulum, 2) membutuhkan waktu yang lama untuk guru sehingga kebanyakan guru tidak mau menggunakan strategi belajar kooperatif, 3) membutuhkan kemampuan khusus guru sehingga tidak semua guru dapat melakukan atau menggunakan strategi belajar kooperatif, dan 4) menuntut sifat tertentu dari siswa, misalnya sifat suka bekerjasama (Hobri: 2009).

Hasil observasi terhadap penilaian sikap dan nilai hasil belajar pada pelaksanaan tindakan siklus II, terlihat adanya peningkatan. Dengan pendekatan dan pemberian motivasi kepada siswa, terlihat siswa lebih aktif dan bersemangat dalam melaksanakan diskusi dalam kelompoknya. Keaktifan siswa pada pelaksanaan di siklus ini meningkat, dan berdampak pada proses pemahaman materi pelajaran oleh siswa menjadi lebih mudah, sehingga terjadi peningkatan juga pada nilai hasil belajar siswa. Pada pelaksanaan tindakan siklus II ini, peneliti juga mengatur waktu secara ketat, sehingga pelaksanaan pembelajaran berjalan secara efektif dan efisien. 


\section{Vol. 1 No. 4 November 2021 e-ISSN : 2775-2593 | p-ISSN : 2775-2585}

Dalam penelitian ini, peningkatan ketercapaian hasil belajar pada pelaksanaan tindakan siklus I dan siklus II seperti tercantum pada tabel di bawah.

Tabel 5. Peningkatan hasil belajar siswa pada aspek afektif

\begin{tabular}{lll}
\hline Aspek Penilaian & \multicolumn{2}{l}{ Tingkat Ketercapaian (\%) } \\
\cline { 2 - 3 } & Observasi I & Observasi II \\
\hline Sikap & 74 & 95 \\
\hline
\end{tabular}

Tabel 6. Peningkatan hasil belajar siswa dari aspek kognitif

\begin{tabular}{llc}
\hline Nilai & \multicolumn{2}{l}{ Tingkat Ketercapaian (\%) } \\
\cline { 2 - 3 } & Evaluasi I & Evaluasi II \\
\hline $80-95$ & 58 & 87 \\
\hline
\end{tabular}

Peningkatan ketercapaian hasil belajar pada pelaksanaan tindakan siklus I dan siklus II juga disajikan dalam bentuk grafik di bawah.

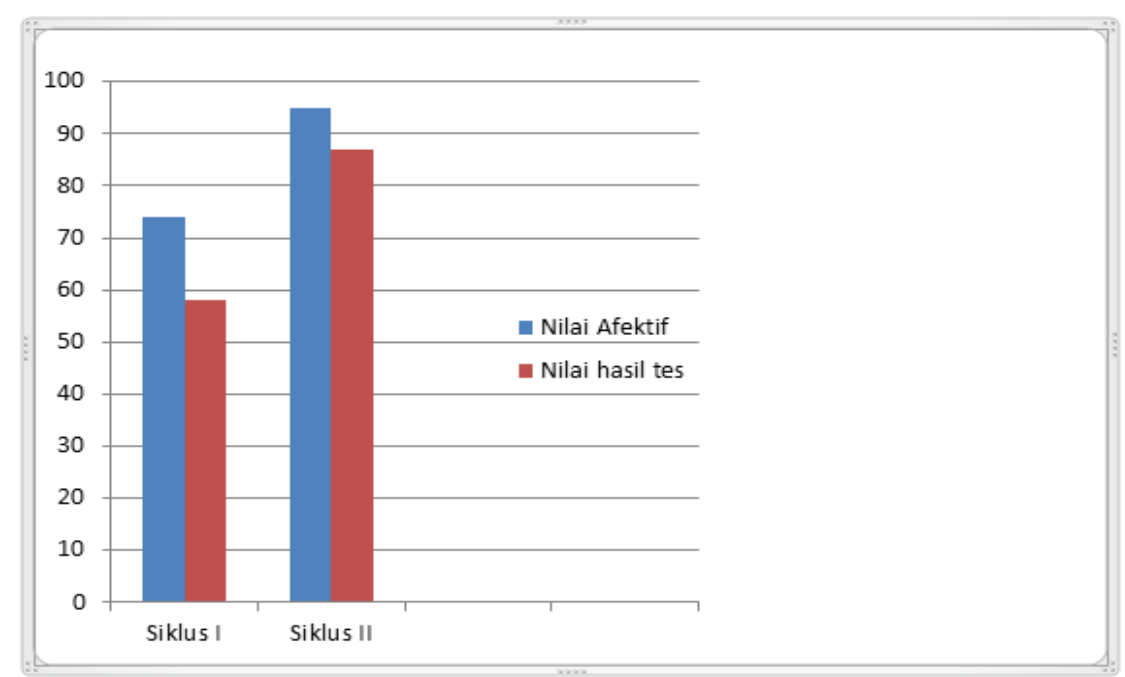

\section{Gambar 4. Grafik peningkatan hasil belajar siswa}

Pada pelaksanaan tindakan siklus I terdapat $74 \%$ siswa mendapatkan nilai sikap $\geq \mathrm{B}$, sementara pada pelaksanaan tindakan siklus II terjadi peningkatan, yaitu 95\% siswa dalam kelas mendapatkan nilai sikap $\geq B$. Nilai hasil belajar siswa pada pelaksanaan tindakan siklus I belum mencapai ketuntasan, karena hanya $58 \%$ siswa mendapatkan nilai $\geq 80$, sementara pada pelaksanaan tindakan siklus II, $87 \%$ siswa di dalam kelas telah mencapai ketuntasan secara individu sehingga ketuntasan secara klasikal juga tercapai

Peningkatan hasil belajar siswa menunjukkan terjadinya peningkatan pemahaman siswa terhadap materi pelajaran. Hal ini sesuai dengan pernyataan bahwasanya sebagian pakar percaya bahwa sebuah mata pelajaran baru benar-benar dikuasai ketika si pembelajar mampu mengajarkannya kepada orang lain. Pengajaran sesama siswa memberi siswa kesempatan untuk mempelajari sesuatu dengan baik dan sekaligus menjadi nara sumber bagi satu sama lain (Melvin: 2016).

Penelitian sebelumnya yang berkaitan dengan model pembelajaran Group To Group Exchange adalah penelitian tindakan kelas dengan judul "Penerapan Strategi Pembelajaran Group to Group Exchange (GGE) Untuk Meningkatkan Motivasi dan Hasil Belajar Siswa Kelas XI IA SMA Negeri 1 Kuantan Hilir Tahun Pelajaran 2010/2011”. (Rosmaini S, Nursal, 
\& Resi Noprianti, 2011). Penelitian ini bertujuan untuk meningkatkan motivasi dan hasil belajar biologi pada siswa.

Merujuk hasil penelitian oleh (Rosmaini S, Nursal, \& Resi Noprianti, 2011) yang dimuat dalam "biogenesis.ejournal.unri.ac.id", nilai rata-rata hasil ulangan harian pada siklus I adalah 75,48. Dengan Kriteria Ketuntasan Minimum (KKM) 65, terhitung 82\% siswa sudah mencapai ketuntasan. Sementara itu pada pelaksanaan siklus II, nilai rata-rata siswa adalah 81,09 dan sebanyak $100 \%$ siswa sudah mencapai ketuntasan belajar. Perbedaan prosentase ketuntasan siswa yang cukup besar pada penelitian ini, dibandingkan dengan penelitian yang dilakukan oleh Rosmaini dkk di atas, disebabkan oleh KKM yang berbeda. Di sekolah peneliti, KKM untuk mata pelajaran kimia adalah 80.

Berdasarkan paparan hasil penelitian di atas, peneliti menyimpulkan bahwa pengaturan waktu yang tepat oleh guru dan pendekatan yang masif kepada siswa, menjadikan siswa termotivasi untuk saling mendukung teman dalam kelompoknya. Siswa yang mempunyai potensi lebih dibanding teman lainnya secara aktif membantu siswa yang kurang mampu. Dengan demikian model Group to Group Exchange dapat meningkatkan pemahaman siswa kelas XI SMA Negeri 2 Jember tahun pelajaran 2018/2019 terhadap pokok bahasan Senyawa Hidrokarbon.

\section{KESIMPULAN}

Keterampilan guru dalam mengelola pembelajaran kooperatif, serta motivasi diri siswa tentang pentingnya bekerja secara kooperatif, menjadikan siswa lebih aktif dalam melaksanakan pembelajaran kooperatif. Mengerjakan lembar kegiatan yang berbeda antar satu kelompok dengan kelompok yang lain membuat siswa lebih bersemangat untuk keunggulan kelompoknya. Diskusi kelompok dengan dibimbing guru menjadikan anak lebih siap dalam mempresentasikan hasil kerja kelompoknya.

Berdasarkan hasil penelitian dan analisis data pada pelaksanaan penelitian tindakan kelas ini, terdapat peningkatan nilai, baik nilai afektif maupun nilai hasil belajar siswa. Dari data kegiatan penelitian ini, dapat disimpulkan bahwa model pembelajaran Group to Group Exchange dapat meningkatkan hasil belajar siswa dalam pokok bahasan Senyawa Hidrokarbon pada siswa kelas XI SMAN 2 Jember. Untuk selanjutnya model pembelajaran Group to Group Exchange bisa digunakan untuk meningkatkan hasil belajar siswa pada pokok bahasan kimia yang lain.

\section{DAFTAR PUSTAKA}

Hobri. (2009). Model-Model Pembelajaran Inovatif. Jember: Center for Society Studies (CSS) Mulyasa. (2004). Kurikulum Berbasis Kompetensi, Konsep, Karakteristik dan Implementasinya. Bandung: Remaja Rosdakarya.

Nurhadi dan Senduk, Agus Gerrad. (2003). Pembelajaran Kontekstual (Contextual Teaching and Learning/CTL) dan Penerapannya dalam KBK.Malang : UNEMA

Purba, Michael. (2000). Kimia 2000 IA. Jakarta :Erlangga

Rosmaini S, Nursal, \& Resi Noprianti, (2011). Penerapan Strategi Pembelajaran Group to Group Exchange (GGE) Untuk Meningkatkan Motivasi dan Hasil Belajar Siswa Kelas XI IA SMA Negeri 1 Kuantan Hilir Tahun Pelajaran 2010/2011. Jurnal. from https://biogenesis.ejournal.unri.ac.id/index.php/JPSB/article/view/676/669

Silberman, Melvin L. (2016). Active Learning 101 Cara Belajar Siswa Aktif. Bandung : Nuansa Cendekia

Sudarmo, Unggul. (2017). Kimia Untuk SMA/MA Kelas XI. Surakarta: Erlangga

Suharsimi, Arikunto, dkk. (2006). Penelitian Tindakan Kelas. Jakarta: PT. Bumi Aksara. 